\title{
Genetic Survey of Autosomal Recessive Peripheral Neuropathy Cases Unravels High Genetic Heterogeneity in a Turkish Cohort
}

Ayşe Candayan, PhD, Arman Çakar, MD, Gulshan Yunisova, MD, Ayşe Nur Özdağ Acarlı, MD, Derek Atkinson, PhD, Pınar Topaloğlu, MD, Hacer Durmuş, MD, Zuhal Yapıcı, MD, Albena Jordanova, PhD, Yeşim Parman, MD, and Esra Battaloğlu, PhD

Neurol Genet 2021;7:e621. doi:10.1212/NXG.0000000000000621

\section{Abstract}

\section{Background and Objectives}

Inherited peripheral neuropathies (IPNs) are a group of genetic disorders of the peripheral nervous system in which neuropathy is the only or the most predominant clinical feature. The most common type of IPN is Charcot-Marie-Tooth (CMT) disease. Autosomal recessive CMT (ARCMT) is generally more severe than dominant CMT and its genetic basis is poorly understood due to high clinical and genetic diversity. Here, we report clinical and genetic findings from 56 consanguineous Turkish families initially diagnosed with CMT disease.

\section{Methods}

We initially screened the GDAP1 gene in our cohort as it is the most commonly mutated ARCMT gene. Next, whole-exome sequencing and homozygosity mapping based on wholeexome sequencing (HOMWES) analysis was performed. To understand the molecular impact of candidate causative genes, functional analyses were performed in patient primary fibroblasts.

\section{Results}

Biallelic recurrent mutations in the GDAP1 gene have been identified in 6 patients. Wholeexome sequencing and HOMWES analysis revealed 16 recurrent and 13 novel disease-causing alleles in known IPN-related genes and 2 novel candidate genes: 1 for a CMT-like disease and 1 for autosomal recessive cerebellar ataxia with axonal neuropathy. We have achieved a potential genetic diagnosis rate of $62.5 \%$ (35/56 families) in our cohort. Considering only the variants that meet the American College for Medical Genetics and Genomics (ACMG) classification as pathogenic or likely pathogenic, the definitive diagnosis rate was $55.35 \%$ (31/56 families).

\section{Discussion}

This study paints a genetic landscape of the Turkish ARCMT population and reports additional candidate genes that might help enlighten the mechanism of pathogenesis of the disease.
Correspondence

Dr. Battaloğlu

battalog@boun.edu.tr 


\section{Glossary}

ACMG = American College for Medical Genetics and Genomics; ARCMT = autosomal recessive CMT; CMT = CharcotMarie-Tooth; FRDA = Friedreich's ataxia; IPN = inherited peripheral neuropathy; $\mathbf{m N C V}=$ motor nerve conduction velocity; NGS = next-generation sequencing; SIFT = sorting intolerant from tolerant; WES = whole-exome sequencing.

Inherited peripheral neuropathies (IPNs) are a group of clinically and genetically diverse disorders of the peripheral nervous system in which neuropathy is the only or the most predominant clinical feature. ${ }^{1}$ The most common type of IPN is hereditary motor and sensory neuropathy, generally referred to as CharcotMarie-Tooth (CMT) disease, named after the 3 neurologists who first reported the clinical features. ${ }^{2}$ Widespread population analyses are very limited to pinpoint the true prevalence of CMT; however, recent population-based studies report a prevalence between 9.7 and 82.3 in 100,000 individuals. ${ }^{3}$ The clinical progression of the disease is characterized by prominent lengthdependent muscle weakness and sensory loss with commonly observed foot deformities such as pes cavus. ${ }^{1,2}$

Historically, CMT is classified into 2 broad groups by evaluating the clinical features of the patient: an upper limb motor nerve conduction velocity ( $\mathrm{mNCV}$ ) less than $38 \mathrm{~m} / \mathrm{s}$ suggests a demyelinating pathology (also called CMT1), whereas a velocity above $38 \mathrm{~m} / \mathrm{s}$ suggests an axonal pathology (also called CMT2). ${ }^{4}$ Later, an additional subtype was introduced into the literature as intermediate CMT (CMT-I) for individuals with an upper limb mNCV between 25 and $45 \mathrm{~m} / \mathrm{s}^{5}$ As the field advanced, a further subclassification was used that assigns different letters to phenotypically classified subtypes according to the causative gene. ${ }^{6}$ More recently, a new classification was proposed that uses abbreviations for inheritance type, phenotypical form of the disease, and the genetic cause. ${ }^{7,8}$

The first CMT-causing genetic locus was identified in $1982,{ }^{9}$ and, at the time of writing, more than 90 distinct disease-causing genes were reported. ${ }^{10-12}$ Investigation of novel causative genes was initially performed by genetic linkage analyses in large pedigrees, positional cloning, or candidate gene approaches, whereas the Human Genome Project and subsequent advances in nextgeneration sequencing (NGS) technologies have led to a great acceleration in the number of CMT-causing genes and mutations. ${ }^{11,13}$ However, even with the widespread use of advanced NGS technologies, only about $45 \%-60 \%$ of patients with CMT receive genetic diagnosis worldwide, suggesting that the number of CMT-causative genes will increase by time. ${ }^{11,1417}$

In the current study, we evaluated 56 Turkish families likely representing an autosomal recessive CMT (ARCMT) cohort. In the strategy used, initially GDAP1 was screened for causative variants in the cohort, followed by a combination of wholeexome sequencing and homozygosity mapping with HOMWES approach. This allowed us to reach a potential genetic diagnosis rate of $62.5 \%$ (35/56 families) and identify 2 novel candidate genes: 1 of which is likely causative for ARCMT disease with atypical features and 1 for autosomal recessive cerebellar ataxia with axonal peripheral neuropathy. The genetic data should be considered cautiously since large datasets for control individuals of Turkish origin are limited in the literature.

\section{Methods}

\section{Patient Cohort}

A total of 180 individuals including affected and unaffected members from 56 unrelated families from different regions in Turkey have been analyzed in this study. The index patients from each family were evaluated by expert neurologists and were initially diagnosed with CMT. Among these 56 families, 27 had a family history of CMT with multiple affected individuals, whereas 29 families had a single affected individual born to consanguineous parents. Age at onset was in childhood in 52 index cases and in adulthood in 4 families. Over $50 \%$ of index patients studied had a severe phenotype with additional clinical features, such as severe scoliosis, hearing loss, vocal cord involvement, and intellectual disability along with symmetrical distal weakness. The presence of CMT1A duplication or hereditary neuropathy with pressure palsies deletion was excluded in all patients using short tandem repeat markers. ${ }^{18}$ Acquired neuropathy was excluded for all patients in the clinical setting. Therefore, the patients studied here most likely represented an ARCMT cohort.

\section{Standard Protocol Approvals, Registrations, and Patient Consents}

The study was approved by the Human Research Ethics Committees of Istanbul University (45103048) and Boğaziçi University (FMINAREK-2018/05). All participants (or guardians of participants) enrolled in the study signed an informed consent for research. STROBE cohort checklist was used when writing the report. ${ }^{19}$

\section{Genetic Analyses}

Peripheral blood samples from 180 individuals (56 families) were obtained, and genomic DNA was purified from these samples. All DNA samples were barcoded anonymously with a unique family identifier and kept refrigerated until further use.

The first step of the analysis was screening of the coding regions of the GDAP1 gene using PCR and subsequent Sanger sequencing. The patients with a GDAP1 mutation previously identified as disease-causing (a recurrent mutation) were excluded from further analyses. Next, wholeexome sequencing was performed using the Illumina NextSeq 
500 device with Illumina Nextera rapid capture kit for the patients without a GDAP1 recurrent mutation. Whole-exome sequencing (WES) data quality was confirmed by combining paired-end and single-end binary alignment map files, excluding repetitions, and excluding variants with a coverage less than 50X. An average of 20,000 different variants were observed in each index patient. Initially, WES data were filtered for variants in a data set of known causative genes for IPN: synonymous and deep intronic variants and variants with alternative allele frequency over $5 \%$ in the general population were filtered out. Recurrent disease-causing mutations identified in patients using this approach were verified in index cases using Sanger sequencing. In a number of patients, novel variants were identified in known disease-causing genes that were not previously reported in databases as disease causing. For these patients, the segregation of variants was verified in the proband and their available affected or unaffected family members using Sanger sequencing. For the variants that fit the inheritance pattern in the family, possible diagnoses were considered when the referring clinician approved the genotype/phenotype correlation.

Finally, the patients who could not be genetically diagnosed by this procedure were further analyzed for disease-causing gene discovery. For this purpose, homozygosity mapping based on wholeexome sequencing analysis (HOMWES) software (genomecomb. sourceforge.net/releases/release0.11.0.html) was used to determine the homozygous regions in patient exomes as previously described. ${ }^{20}$ To search for novel candidate genes in these patients, variants that reside in the large homozygous regions identified by HOMWES were prioritized. Variant filtering was performed with strict parameters: variants with a read depth of less than 30, variants with alternative allele frequency over $1 \%$, and variants that were predicted to be benign/tolerated by both sorting intolerant from tolerant (SIFT) and PolyPhen2 algorithms were excluded. Candidate variants were then verified in the proband and their affected or unaffected family members with Sanger sequencing. ToppGene (toppgene.cchmc.org/prioritization.jsp) and Endeavour (homes.esat.kuleuven.be/;bioiuser/endeavour/tool/endeavourweb.php) algorithms were used to prioritize among the multiple candidate genes. All genetic findings were analyzed for American College for Medical Genetics and Genomics (ACMG) criteria and classified according to this guideline. ${ }^{21}$

\section{Data Availability}

Whole-exome sequencing data of all participants are present in the Genesis Platform (tgp-foundation.org/g-e-n-e-s-i-s). All variants reported here are submitted to the ClinVar database and can be found in accession numbers SCV001548301SCV001548332. Additional data can be made available on reasonable request.

\section{Results}

\section{Mutations in the GDAP1 Gene}

Mutations in the GDAP1 gene are the most common cause of ARCMT disease with a frequency of $10 \%-15 \%$ in ARCMT cases. $^{22,23}$ Therefore, we initially screened our cohort for mutations in this gene. As expected, 6 patients were shown to carry recurrent homozygous mutations in GDAP1 (eTable 1, links.lww.com/NXG/A464). Families 5, 12, 26, and 42 had c.786del, p.Phe263Leufs*22 variant, family 9 had c.174 176delinsTGTG, p.Pro59Valfs*4 variant, and family 50 had c.458C $>\mathrm{T}$, p.Pro153Leu variant, all in homozygous condition. These patients with recurrent GDAP1 mutations were excluded from further analyses. The clinical and genetic findings of all 56 patients enrolled in the study are given in eTable 1 , links.lww.com/NXG/A464.

\section{Whole-Exome Sequencing}

WES was performed for 50 patients, and among those, 16 were genetically diagnosed by filtering for recurrent variants in known IPN-causing genes. Among these, 1 patient was shown to carry a recurrent mutation (c.2182C $>\mathrm{T}$, p.Arg728Ter) in the SACS gene, which is a known causative gene for autosomal recessive spastic ataxia of CharlevoixSaguenay. ${ }^{24}$ The clinical re-evaluation revealed that the patient developed mild spasticity, positive Babinski sign, and cerebellar ataxia after his initial referral for genetic analysis.

We have identified 13 further candidate variants in known IPN genes that were not previously reported as disease causing. These variants were shown to fit the segregation of the disease in the pedigree, and the referring clinicians suggested that the corresponding genes could explain the clinical representation of each patient. Seven of these 13 patients carried homozygous termination or frameshift mutations in genes that were reported to be disease causing due to loss of function. These 7 mutations were in $M M E$ (homozygous, c.531del, p.Lys177Asnfs*15), HINT1 (homozygous, c.99del, p.Phe33Leufs*22), NDRG1 (homozygous, c.237C>A; p.Tyr79Ter), NEFL (homozygous, c.54C $>$ A, p.Tyr18Ter), GDAP1 (homozygous, c.112C $>\mathrm{T}$, p.Gln38Ter), C12ORF65 (homozygous, c.18_21del, p.Leu6Phefs*7), and SH3TC2 (homozygous, c.54dup, p.Lys19Ter) genes, and they were classified as pathogenic or likely pathogenic according to the ACMG criteria. The other 6 patients were homozygous for missense mutations; thus, pathogenicity could not be assessed solely on familial segregation analysis. Still, 2 of those alleles (homozygous c.1586G $>$ A; p.Arg529His variant in SH3TC2 and homozygous c.271G>T; p.Val91Leu variant in MFN2 genes) were classified as likely pathogenic according to the ACMG criteria because, in addition to other supporting evidence, these variants were observed in the same codon where a different missense change was reported as pathogenic previously (CM033080 and CM127950 for SH3TC2; CM117904 for MFN2 in HGMD). The remaining 4 missense variants with unknown significance were in $S P G 7$ (c.454A $>\mathrm{G}$, p.Met152Val), AP5Z1 (c.1568G>A, p.Arg523His), SBF2 (c.2549T>C, p.Met850Thr), and MPZ (c.362A >G, p.Asp121Gly) genes (eTable 1, links.lww.com/NXG/A464).

Although the cohort represented possible recessive inheritance based on declared parental consanguinity, pedigree 


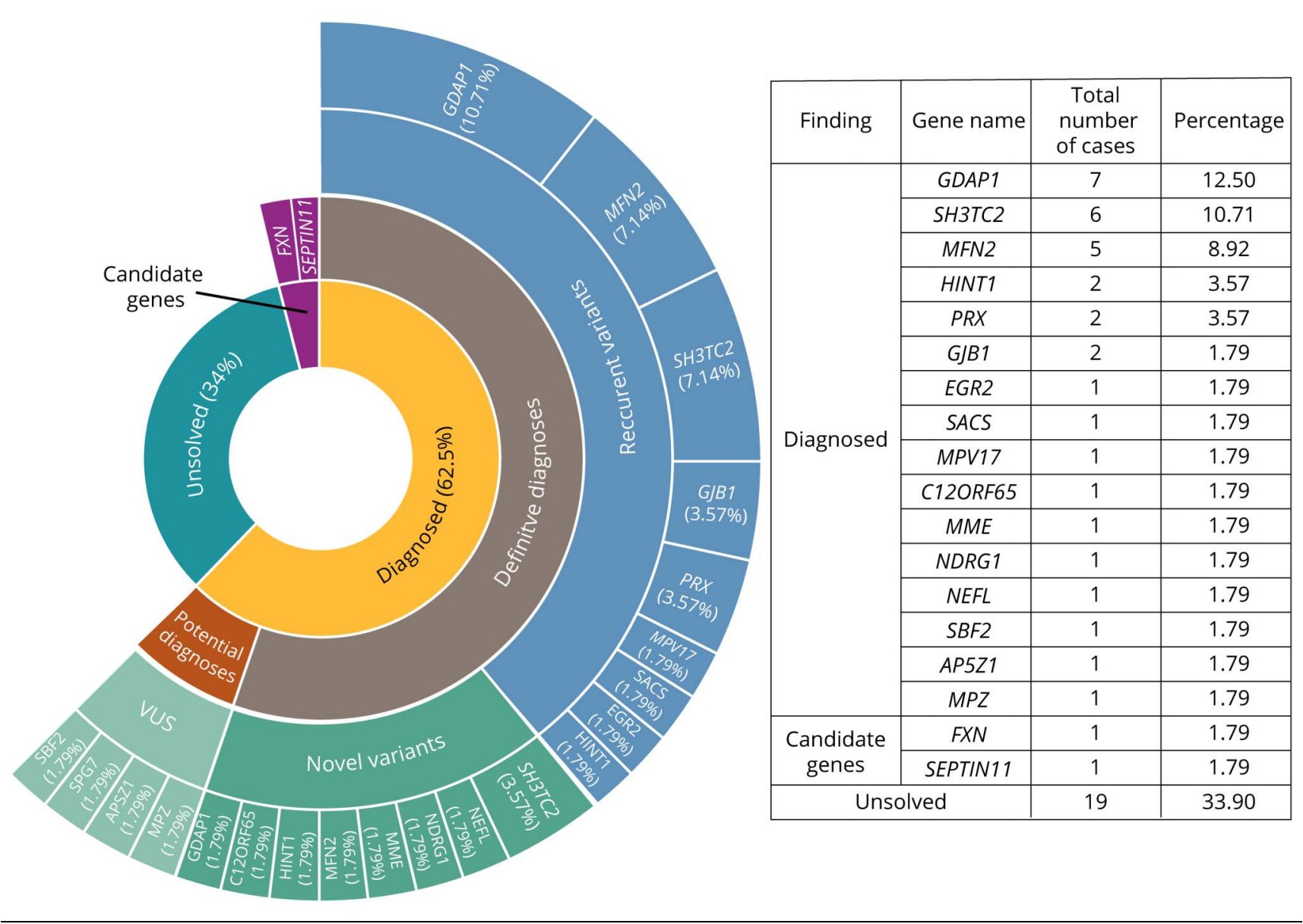

analysis, and/or severity of symptoms, pathogenic dominant mutations have also been observed. Families 32, 52, and 53 were shown to carry recurrent heterozygous mutations in the MFN2 gene and family 43 to carry a novel heterozygous MPZ variant of unknown significance. Besides, family 51 was shown to have a recurrent disease-causing mutation in the GJB1 gene.

\section{Novel Candidate Genes}

We have used homozygosity mapping on WES data to unravel the causative loci for the remaining undiagnosed 21 families. This analysis revealed 2 candidate disease-causing genes.

An isolated pediatric patient (family 39) had a biallelic frameshift variant in the SEPTIN11 gene (c.265dup; p.Glu89Glyfs*12). Her symptoms started with walking difficulty at age 7 years. Dysmetria, dysdiadochokinesia, and truncal ataxia were her prominent findings during neurologic examination. She had additional axonal sensorimotor polyneuropathy prominent in the lower extremities and hypertrophic cardiomyopathy. Her visual evoked potential examination revealed bilateral symmetrical prolongation of latencies. The p.Glu89Glyfs*12 variant in SEPTIN11 was not reported in population databases. Besides, MutationTaster (mutationtaster.org/) algorithm predicted the variant to cause nonsense-mediated mRNA decay.
qPCR and Western blotting analyses performed on the skin fibroblasts of the proband showed significantly decreased expression of Septin $11 \mathrm{mRNA}$ and protein, respectively (data not shown). We could not identify an additional family with a mutation in the same gene in our patient cohort, through GeneMatcher (genematcher.org/) or Genesis Platform (tgpfoundation.org/).

In family 24, we have identified a biallelic missense variant in the FXN gene (c.493C>T; p.Arg165Cys), which is a known causative gene for Friedreich ataxia. Three affected siblings in this family (24) were homozygous for the variant and presented a CMT-like phenotype. The clinical features of this family and the genetic findings were reported previously. ${ }^{25}$

\section{Diagnostic Outcome of the Analyses}

The initial screening of the patients for founder GDAP1 mutations in the Turkish population revealed that about $10 \%$ of the cohort has causative mutations in this gene. WES analysis identified the causative genes in 29 additional cases. Among these, 16 cases had recurrent and 13 had novel variants in known IPN-related genes. This approach for screening known disease-causing genes allowed genetic diagnosis of $62.5 \%(35 / 56)$ of families in our cohort. Nine of the novel deleterious variants met the ACMG variant classification as 
likely pathogenic or pathogenic. The other 4 were missense variants of unknown significance and need further molecular analyses to assess pathogenicity. When these 4 cases are not considered as definitive diagnoses, the diagnostic rate remains to be $55.35 \%$ (31/56 cases). Diagnostic outcome of the study is summarized in Figure 1.

\section{Discussion}

In this study, genetic survey of 56 index patients with CMT unraveled the genetic causes of autosomal recessive subtypes in the Turkish population and allowed identification of 2 novel candidate genes. The GDAP1 gene was the most commonly mutated gene in $12.5 \%$ of the cases. WES analysis allowed further identification of causative variants in 29 patients in known genes for CMT or other related neuronopathies. Nine of 13 novel variants were likely pathogenic or pathogenic according to the ACMG criteria, whereas 4 variants were of unknown significance. Thus, we provided genetic diagnosis in 35 patients $(62.5 \%), 31$ of which were definitive $(55.35 \%)$. In family 24 , we defined a new gene-disease relationship and showed that biallelic FXN missense mutations are not lethal, but can cause a CMT-like phenotype, rather than Friedreich's ataxia (FRDA), as reported previously. ${ }^{25}$ In another family (39), we identified SEPTIN11 as a novel candidate disease-causing gene for autosomal recessive cerebellar ataxia with axonal peripheral neuropathy.

The overall definitive genetic diagnosis rate in our study was $55.35 \%$ in accordance with $45 \%-60 \%$, reported by previous studies. ${ }^{11,14,15,17,26}$ In our cohort, GDAP1 gene mutations were the most common genetic cause (12.5\%, $7 / 56$ patients), followed by mutations in SH3TC2 (10.7\%, 6/56 patients). In similar studies examining patients with ARCMT, the mutation frequency in GDAP1 was reported to be $10 \%-15 \%$, and the mutation frequency in SH3TC2 was 7.5\%. ${ }^{22,23}$ Thus, the commonly mutated genes were also in correlation with the previously reported population frequencies. MFN2 was the third most commonly mutated gene, with 5 families (8.9\%), and HINT1, PRX, and GJB1 mutations were observed in 2 families (3.6\% each). Mutations in AP5Z1, C12ORF65, EGR2, MME, MPV17, MPZ, NDRG1, NEFL, SACS, SBF2, and $S P G 7$ genes were observed only once in our cohort.

We have identified recurrent heterozygous mutations in the MFN2 gene in 3 families and a novel heterozygous MPZ variant in 1 family implicating dominant cases in a possible recessive inheritance cohort. Besides, 1 family was shown to have a recurrent disease-causing mutation in the GJB1 gene. Thus, it is advisable to focus on known disease genes, but not particularly on inheritance pattern during initial variant filtering. Otherwise, we would have missed these variants in genes responsible for autosomal dominant and X-linked forms of the disease. It should also be noted that diseasecausing mutations in MFN2 and MPZ could occur sporadically and expressivity could be low for some individuals. ${ }^{27}$
The filtering criteria used to evaluate WES data generally include the nucleotide changes caused by the variant (such as substitutions, short indels, frameshifts, and changes in regulatory regions), alternative allele frequency, and pathogenicity scores predicted by SIFT and PolyPhen2. ${ }^{28}$ Read depth is usually used as a filtering criterion to remove false positives from the data. In our study, although the variants in the known IPN genes were examined, read depth or pathogenicity predictions were not used as filtering criteria initially, and the alternative allele frequency was set to less than $5 \%$, which could be considered as a wide range. Still, we did not encounter a high number of false-positive results and found out that the use of this initial relaxed filtering criteria allowed us to reach a relatively high genetic diagnosis rate. Furthermore, although all patients enrolled were initially diagnosed with CMT, genetic findings suggested overlapping neurologic disorders for some patients. Thus, investigating causative genes for related disorders, as well as CMT-causing genes, in data analysis also improved genetic diagnosis rate. To all our efforts, we could not identify the genetic cause in about $40 \%$ of patients, which can be attributed to disadvantages of $\mathrm{WES},{ }^{29,30}$ but also underlines the genetic heterogeneity of IPN and points to the presence of unknown causative genes or perhaps to nonmendelian characteristics. ${ }^{31}$

Apart from providing a genetic overview of ARCMT in Turkey, we have identified 2 potential candidate genes. One of the families (24) had a homozygous missense FXN mutation with a CMT-like disease, instead of FRDA. To the best of our knowledge, this case was the first family reported in literature with a biallelic missense mutation in this gene, and the findings challenge the idea that these mutations cause embryonic lethality, as suggested previously. ${ }^{32}$ This finding represents a novel phenotype in the clinical spectrum between CMT and FRDA for which the clinical findings were reported previously. ${ }^{25}$ Another family we identified in this study (39) has a biallelic frameshift mutation in the SEPTIN11 gene. The clinical features of the index patient revealed cerebellar ataxia, axonal sensorimotor polyneuropathy, and hypertrophic cardiomyopathy. Unfortunately, we were not able to find any additional families with similar clinical features and genetic findings through matchmaking tools including GeneMatcher and Genesis Platform. However, we found that Septin 11 mRNA and protein was significantly reduced in patient skin fibroblasts (data not shown). Septin 11 protein was shown to be highly expressed in intact mouse cerebellum, particularly in Purkinje cells and the knockdown of Septin 11 reduced dendritic branching and spine density, while increasing the length of dendritic protrusions in cultured murine hippocampal neurons. ${ }^{33}$ The clinical features of our patient can be explained by these alterations in the neuronal cytoarchitecture due to reduced expression of Septin 11 caused by the biallelic frameshift mutation. Therefore, SEPTIN11 should be considered as a causative gene for autosomal recessive cerebellar ataxia with axonal neuropathy, and patients with similar phenotypes should be screened for mutations in this gene. 
In conclusion, we have analyzed a cohort of 56 consanguineous Turkish families with likely autosomal recessive peripheral neuropathy and provided genetic diagnoses to about 55\% (31/ 56) of the patients. Our genetic diagnosis rate is one of the highest reported in the literature, and we believe that this is achieved by initially analyzing the data with relaxed filtering criteria and not restricting the analysis to CMT-causative genes. We have identified 22 families with 17 distinct recurrent mutations, as well as 13 families with novel alleles in known IPNrelated genes, suggesting a rather high heterogeneity in this cohort. We believe that our study provides a genetic overview of the ARCMT population in Turkey and can provide a reference for genetic diagnosis strategies for populations with similar genetic background. In accordance with one of the main objectives of the study, we have identified 2 novel candidate diseasecausing genes in this cohort. We suggest that biallelic FXN and SEPTIN11 mutations should also be screened in patients with relevant clinical features. Based on our findings with marked genetic heterogeneity in this cohort, we suggest use of gene panels or whole-exome sequencing rather than single gene screening in populations with high consanguinity rate.

\section{Acknowledgment}

The authors thank all affected individuals and their family for their collaboration.

\section{Study Funding}

This study was financially supported by TUBITAK grant number $215 S 883$ and Bogazici University BAP grant number 17304 to E.B. and Turkish Neurologic Society collaboration and support award to A.C.

\section{Disclosure}

The authors report no disclosures relevant to the manuscript. Go to Neurology.org/NG for full disclosures.

\section{Publication History}

Received by Neurology: Genetics April 9, 2021. Accepted in final form June 15, 2021.

\section{Appendix Authors}

\begin{tabular}{lll}
\hline Name & Location & Contribution \\
\hline $\begin{array}{l}\text { Ayşe } \\
\text { Candayan, } \\
\text { PhD }\end{array}$ & $\begin{array}{l}\text { Department of Molecular } \\
\text { Biology and Genetics, } \\
\text { Boğaziçi University, Istanbul, } \\
\text { Turkey }\end{array}$ & $\begin{array}{l}\text { Drafting/revision of the } \\
\text { manuscript for content, } \\
\text { including medical writing for } \\
\text { content; major role in the } \\
\text { acquisition of data; study } \\
\text { concept or design; and analysis } \\
\text { or interpretation of data }\end{array}$ \\
\hline $\begin{array}{l}\text { Arman } \\
\text { Çakar, MD }\end{array}$ & $\begin{array}{l}\text { Neuromuscular Unit, } \\
\text { Department of Neurology, } \\
\text { Istanbul Faculty of Medicine, }\end{array}$ & $\begin{array}{l}\text { Drafting/revision of the } \\
\text { manuscript for content, } \\
\text { including medical writing for } \\
\text { content, and major role in the } \\
\text { Istanbul University, Turkey }\end{array}$ \\
& & acquisition of data \\
\hline $\begin{array}{l}\text { Gulshan } \\
\text { Yunisova, } \\
\text { MD }\end{array}$ & $\begin{array}{l}\text { Neuromuscular Unit, } \\
\text { Department of Neurology, } \\
\text { Istanbul Faculty of Medicine, } \\
\text { Istanbul University, Turkey }\end{array}$ & $\begin{array}{l}\text { Major role in the acquisition } \\
\text { of data }\end{array}$ \\
\hline
\end{tabular}

\section{Appendix (continued)}

\begin{tabular}{|c|c|c|}
\hline Name & Location & Contribution \\
\hline $\begin{array}{l}\text { Ayşe Nur } \\
\text { Özdağ } \\
\text { Acarlı, MD }\end{array}$ & $\begin{array}{l}\text { Neuromuscular Unit, } \\
\text { Department of Neurology, } \\
\text { Istanbul Faculty of Medicine, } \\
\text { Istanbul University, Turkey; } \\
\text { Department of Epigenetics, } \\
\text { Max Planck Institute of } \\
\text { Immunobiology and } \\
\text { Epigenetics, Freiburg, } \\
\text { Germany }\end{array}$ & $\begin{array}{l}\text { Major role in the acquisition } \\
\text { of data }\end{array}$ \\
\hline $\begin{array}{l}\text { Derek } \\
\text { Atkinson, } \\
\text { PhD }\end{array}$ & $\begin{array}{l}\text { Molecular Neurogenomics } \\
\text { Group, VIB-UAntwerp Center } \\
\text { for Molecular Neurology, } \\
\text { University of Antwerp, } \\
\text { Belgium }\end{array}$ & $\begin{array}{l}\text { Drafting/revision of the } \\
\text { manuscript for content, } \\
\text { including medical writing for } \\
\text { content, and analysis or } \\
\text { interpretation of data }\end{array}$ \\
\hline $\begin{array}{l}\text { Pınar } \\
\text { Topaloğlu, } \\
\text { MD }\end{array}$ & $\begin{array}{l}\text { Division of Child Neurology, } \\
\text { Department of Neurology, } \\
\text { Istanbul University, Istanbul } \\
\text { Faculty of Medicine, Turkey }\end{array}$ & $\begin{array}{l}\text { Major role in the acquisition } \\
\text { of data }\end{array}$ \\
\hline $\begin{array}{l}\text { Hacer } \\
\text { Durmuş, } \\
\text { MD }\end{array}$ & $\begin{array}{l}\text { Neuromuscular Unit, } \\
\text { Department of Neurology, } \\
\text { Istanbul Faculty of } \\
\text { Medicine, Istanbul } \\
\text { University, Turkey }\end{array}$ & $\begin{array}{l}\text { Major role in the acquisition } \\
\text { of data }\end{array}$ \\
\hline $\begin{array}{l}\text { Zuhal } \\
\text { Yapıcı, MD }\end{array}$ & $\begin{array}{l}\text { Division of Child Neurology, } \\
\text { Department of Neurology, } \\
\text { Istanbul University, } \\
\text { Istanbul Faculty of } \\
\text { Medicine, Turkey }\end{array}$ & $\begin{array}{l}\text { Major role in the acquisition } \\
\text { of data }\end{array}$ \\
\hline $\begin{array}{l}\text { Albena } \\
\text { Jordanova, } \\
\text { PhD }\end{array}$ & $\begin{array}{l}\text { Molecular Neurogenomics } \\
\text { Group, VIB-UAntwerp Center } \\
\text { for Molecular Neurology, } \\
\text { University of Antwerp, } \\
\text { Belgium; Molecular Medicine } \\
\text { Center, Department of } \\
\text { Medical Chemistry and } \\
\text { Biochemistry, Medical } \\
\text { University-Sofia, Bulgaria }\end{array}$ & $\begin{array}{l}\text { Drafting/revision of the } \\
\text { manuscript for content, } \\
\text { including medical writing for } \\
\text { content, and analysis or } \\
\text { interpretation of data }\end{array}$ \\
\hline $\begin{array}{l}\text { Yeşim } \\
\text { Parman, } \\
\text { MD }\end{array}$ & $\begin{array}{l}\text { Neuromuscular Unit, } \\
\text { Department of Neurology, } \\
\text { Istanbul Faculty of Medicine, } \\
\text { Istanbul University, Turkey }\end{array}$ & $\begin{array}{l}\text { Analysis or interpretation of } \\
\text { data }\end{array}$ \\
\hline $\begin{array}{l}\text { Esra } \\
\text { Battaloğlu, } \\
\text { PhD }\end{array}$ & $\begin{array}{l}\text { Department of Molecular } \\
\text { Biology and Genetics, } \\
\text { Boğaziçi University, Istanbul, } \\
\text { Turkey }\end{array}$ & $\begin{array}{l}\text { Drafting/revision of the } \\
\text { manuscript for content, } \\
\text { including medical writing for } \\
\text { content; major role in the } \\
\text { acquisition of data; study } \\
\text { concept or design; and } \\
\text { analysis or interpretation of } \\
\text { data }\end{array}$ \\
\hline
\end{tabular}

\section{References}

1. Rossor AM, Evans MR, Reilly MM. A practical approach to the genetic neuropathies. Pract Neurol. 2015;15(3):187-198.

2. De Jonghe P, Timmerman V, Nelis E, Martin J-J, Van Broeckhoven C. Charcot-MarieTooth disease and related peripheral neuropathies. J Peripher Nerv Syst. 1997;2(4):370-387.

3. Barreto LC, Oliveira FS, Nunes PS, et al. Epidemiologic study of Charcot-MarieTooth disease: a systematic review. Neuroepidemiology. 2016;46(3):157-165.

4. Harding AE, Thomas PK. The clinical features of hereditary motor and sensory neuropathy types I and II. Brain. 1980;103(2):259-280.

5. Davis CJ, Bradley WG, Madrid R. The peroneal muscular atrophy syndrome: clinical, genetic, electrophysiological and nerve biopsy studies. I. Clinical, genetic and electrophysiological findings and classification. J Genet Hum. 1978;26(4):311-349.

6. Pipis M, Rossor AM, Laura M, Reilly MM. Next-generation sequencing in Charcot-Marie-Tooth disease: opportunities and challenges. Nat Rev Neurol. 2019; 15(11):644-656.

7. Mathis S, Goizet C, Tazir M, et al. Charcot-Marie-Tooth diseases: an update and some new proposals for the classification. J Med Genet. 2015;52(10):681-690. 
8. Magy L, Mathis S, Le Masson G, Goizet C, Tazir M, Vallat J-M. Updating the classification of inherited neuropathies. Neurology. 2018;90(10):e870-e876.

9. Bird TD, Ott J, Giblett ER. Evidence for linkage of Charcot-Marie-Tooth neuropathy to the Duffy locus on chromosome 1. Am J Hum Genet. 1982;34(3):388-394.

10. Pisciotta C, Shy ME. Chapter 42: neuropathy. Handb Clin Neurol. 2018;148:653-665.

11. Timmerman V, Strickland AV, Züchner S Genetics of Charcot-Marie-Tooth (CMT) disease within the frame of the human genome project success. Genes (Basel). 2014;5(1):13-32.

12. Rossor AM, Polke JM, Houlden H, Reilly MM. Clinical implications of genetic advances in Charcot-Marie-Tooth disease. Nat Rev Neurol. 2013;9(10):562-571.

13. Pang SY, Teo KC, Hsu JS, et al. The role of gene variants in the pathogenesis of neurodegenerative disorders as revealed by next generation sequencing studies: a review. Transl Neurodegener. 2017;6(1):27-11.

14. Murphy SM, Laura M, Fawcett K, et al. Charcot-Marie-Tooth disease: frequency of genetic subtypes and guidelines for genetic testing. J Neurol Neurosurg Psychiatry. 2012;83(7):706-710.

15. Baets J, Deconinck T, De Vriendt E, et al. Genetic spectrum of hereditary neuropathies with onset in the first year of life. Brain. 2011;134(9):2664-2676.

16. Saporta AS, Sottile SL, Miller LJ, Feely SM, Siskind CE, Shy ME. Charcot-MarieTooth disease subtypes and genetic testing strategies. Ann Neurol. 2011;69(1):22-33.

17. Pareyson D, Marchesi C. Diagnosis, natural history, and management of CharcotMarie-Tooth disease. Lancet Neurol. 2009;8(7):654-667.

18. Latour P, Boutrand L, Levy N, et al. Polymorphic short tandem repeats for diagnosis of the charcot-marie-tooth 1A duplication. Clin Chem. 2001;47(5):829-837.

19. von Elm E, Altman DG, Egger M, Pocock SJ, Gøtzsche PC, Vandenbroucke JP. The Strengthening the Reporting of Observational Studies in Epidemiology (STROBE) statement: guidelines for reporting observational studies. J Clin Epidemiol. 2008; 61(4):344-349.

20. Kancheva D, Atkinson D, De Rijk P, et al. Novel mutations in genes causing hereditary spastic paraplegia and Charcot-Marie-Tooth neuropathy identified by an optimized protocol for homozygosity mapping based on whole-exome sequencing. Genet Med. 2016;18(6):600-607.

21. Richards S, Aziz N, Bale S, et al. Standards and guidelines for the interpretation of sequence variants: a joint consensus recommendation of the American College of
Medical Genetics and Genomics and the Association for Molecular Pathology. Genet Med. 2015;17(5):405-424.

22. Zimoń M, Battaloğlu E, Parman Y, et al. Unraveling the genetic landscape of autosomal recessive Charcot-Marie-Tooth neuropathies using a homozygosity mapping approach. Neurogenetics. 2014;16(1):33-42.

23. Nelis E, Erdem S, Van den Bergh PY, et al. Mutations in GDAP1: autosomal recessive CMT with demyelination and axonopathy. Neurology. 2002;59(12):1865-1872.

24. Vermeer S, Meijer RP, Pijl BJ, et al. ARSACS in the Dutch population: a frequent cause of early-onset cerebellar ataxia. Neurogenetics. 2008;9(3):207-214.

25. Candayan A, Yunisova G, Çakar A, et al. The first biallelic missense mutation in the FXN gene in a consanguineous Turkish family with Charcot-Marie-Tooth-like phenotype. Neurogenetics. 2020;21(1):73-78.

26. Reilly MM, Murphy SM, Laurá M. Charcot-Marie-Tooth disease. J Peripher Nerv Syst. 2011;16(1):1-14.

27. Nicholson GA, Magdelaine C, Zhu D, et al. Severe early-onset axonal neuropathy with homozygous and compound heterozygous mfn2 mutations. Neurology. 2008;70(19): 1678-1681.

28. Bao R, Huang L, Andrade J, et al. Review of current methods, Applications, and data management for the bioinformatics analysis of whole exome sequencing. Cancer Inform. 2014;13:67-82.

29. Warman Chardon J, Beaulieu C, Hartley T, Boycott KM, Dyment DA. Axons to exons: the molecular diagnosis of rare neurological diseases by next-generation sequencing. Curr Neurol Neurosci Rep. 2015;15(9):1-8.

30. Foley AR, Donkervoort S, Bönnemann CG. Next-generation sequencing still needs our generation's clinicians. Neurol Genet. 2015;1(2):e13-4.

31. Bis-Brewer DM, Fazal S, Züchner S. Genetic modifiers and non-Mendelian aspects of CMT. Brain Res. 2020;1726:146459.

32. Cossée M, Dürr A, Schmitt M, et al. Friedreich's ataxia: point mutations and clinical presentation of compound heterozygotes. Ann Neurol. 1999;45(2):200-206.

33. Li X, Serwanski DR, Miralles CP, Nagata K, De Blas AL. Septin 11 is present in GABAergic synapses and plays a functional role in the cytoarchitecture of neurons and GABAergic synaptic connectivity. J Biol Chem. 2009;284(25): 17253-17265. 


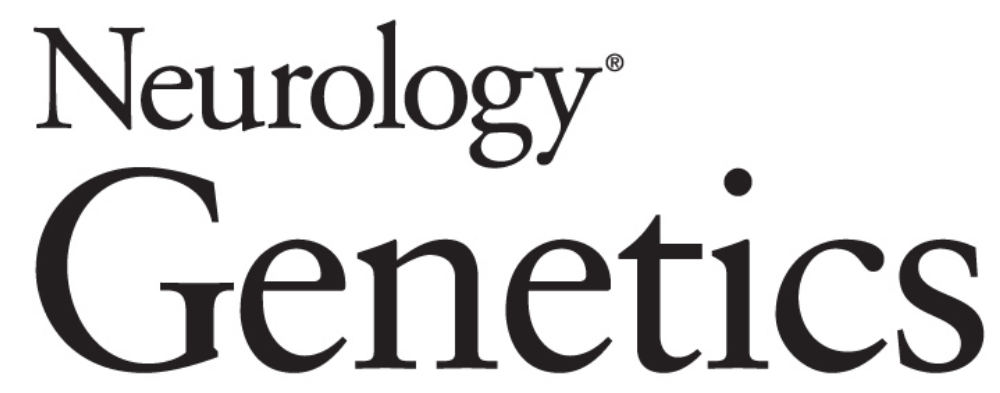

Genetic Survey of Autosomal Recessive Peripheral Neuropathy Cases Unravels High Genetic Heterogeneity in a Turkish Cohort

Ayse Candayan, Arman Çakar, Gulshan Yunisova, et al. Neurol Genet 2021;7;

DOI 10.1212/NXG.0000000000000621

This information is current as of August 31, 2021

Neurol Genet is an official journal of the American Academy of Neurology. Published since April 2015, it is an open-access, online-only, continuous publication journal. Copyright Copyright ( 2021 The Author(s). Published by Wolters Kluwer Health, Inc. on behalf of the American Academy of Neurology.. All rights reserved. Online ISSN: 2376-7839.

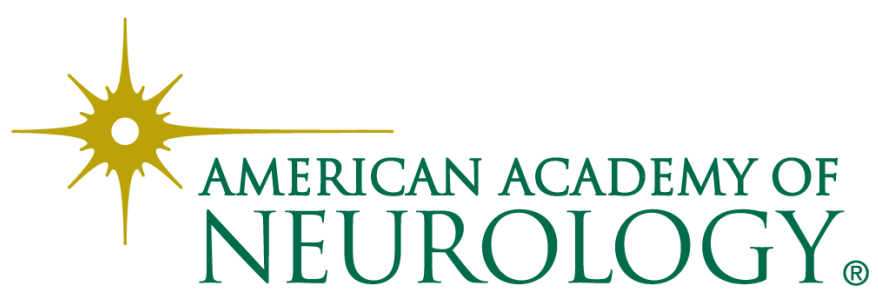




\section{Updated Information \& Services}

\section{References}

Citations

Subspecialty Collections

Errata

Permissions \& Licensing

\section{Reprints}

including high resolution figures, can be found at: http://ng.neurology.org/content/7/5/e621.full.html

This article cites 33 articles, 6 of which you can access for free at: http://ng.neurology.org/content/7/5/e621.full.html\#\#ref-list-1

This article has been cited by 1 HighWire-hosted articles: http://ng.neurology.org/content/7/5/e621.full.html\#\#otherarticles

This article, along with others on similar topics, appears in the following collection(s):

\section{All Genetics}

http://ng.neurology.org//cgi/collection/all_genetics Peripheral neuropathy http://ng.neurology.org//cgi/collection/peripheral_neuropathy

An erratum has been published regarding this article. Please see next page or: /content/8/1/e656.full.pdf

Information about reproducing this article in parts (figures,tables) or in its entirety can be found online at:

http://ng.neurology.org/misc/about.xhtml\#permissions

Information about ordering reprints can be found online: http://ng.neurology.org/misc/addir.xhtml\#reprintsus

Neurol Genet is an official journal of the American Academy of Neurology. Published since April 2015, it is an open-access, online-only, continuous publication journal. Copyright Copyright $\odot 2021$ The Author(s). Published by Wolters Kluwer Health, Inc. on behalf of the American Academy of Neurology.. All rights reserved. Online ISSN: 2376-7839.

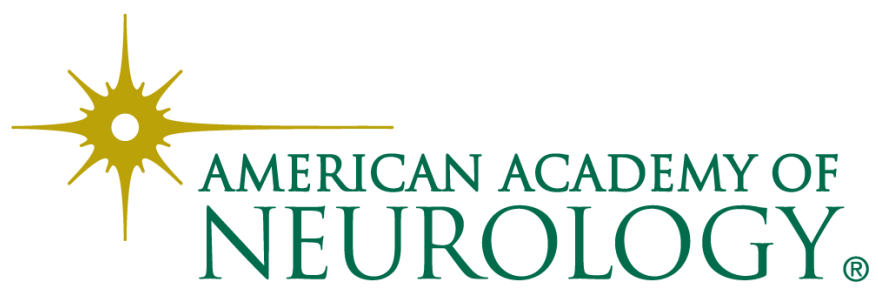




\section{Genetic Survey of Autosomal Recessive Peripheral Neuropathy Cases Unravels High Genetic Heterogeneity in a Turkish Cohort}

Neurol Genet 2022;8:e656. doi:10.1212/NXG.0000000000000656

In the Article "Genetic Survey of Autosomal Recessive Peripheral Neuropathy Cases Unravels High Genetic Heterogeneity in a Turkish Cohort” by Candayan et al. ${ }^{1}$, the affiliations for the fourth and fifth authors listed in the Location column of the Appendix should be as follows. The affiliation for Ayşe Nur Özdağ Acarlı: "Neuromuscular Unit, Department of Neurology, Istanbul Faculty of Medicine, Istanbul University, Turkey." The affiliations for Derek Atkinson: "Molecular Neurogenomics Group, VIB-UAntwerp Center for Molecular Neurology, University of Antwerp, Belgium; Department of Epigenetics, Max Planck Institute of Immunobiology and Epigenetics, Freiburg, Germany." The publisher regrets the errors.

\section{Reference}

1. Candayan A, Çakar A, Yunisova G, et al. Genetic survey of autosomal recessive peripheral neuropathy cases unravels high genetic heterogeneity in a Turkish cohort. Neurol Genet. 2021;7(5):e621. 